\title{
VPLYV PANDÉMIE COVID-19 NA ELEKTRONICKÝ OBCHOD V ROKU 2020
}

\section{Peter Jucha $^{1}$, Tatiana Čorejová ${ }^{2}$}

\begin{abstract}
The COVID-19 pandemic, which affected the whole world, created very difficult conditions in the business environment and significantly affected e-commerce. The aim of the paper is to analyze secondary sources and summarize how the COVID-19 pandemic has affected the e-commerce.
\end{abstract}

Keywords: customer, e-commerce, pandemic, retail sale

\section{Úvod}

Na začiatku roka 2020 takmer nikto netušil k akým zmenám vo svete dôjde. Podniky aj l'udia mali pripravené rozpočty a pomaly začínali s realizáciou svojich plánov. A aj ked' sa už koncom januára začalo hovorit' o novej chorobe, ktorá sa rozšírila v Číne, väčšina obyvatel'ov, či už Ameriky, Európy alebo aj iných kontinentov a krajín, ju vnímala ako vzdialený problém, ktorý sa ich netýkal. Nakoniec ale vírus vo vel'kom prepukol aj v Taliansku odkial' sa rozšíril do celej Európy a následne aj do iných krajín a na ostatné kontinenty vrátane Ameriky. A vzhl'adom na túto skutočnost', Svetová zdravotnícka organizácia formálne vyhlásila, 11. marca 2020, COVID-19 za pandémiu. [1]

Pandémia COVID-19, ktorá nakoniec zasiahla celý svet, vytvorila vel'mi zložité podmienky v podnikatel'skom prostredí a jednotlivé podniky museli čelit', a niektoré dodnes čelia, mnohým výzvam, ktoré sú spojené s uzatváraním medzinárodných hraníc, zatváraním kamenných predajní a obchodov a izolovaním l’udí v ich domácnostiach. Mnoho podnikov bolo nútených čiastočne alebo úplne zatvára svoje prevádzky a mnoho zamestnancov trápila finančná neistota a obavy zo straty zamestnania. [2]

Vírus COVID-19 spôsobil napríklad pokles výroby priemyslu v Č́ne o 13,5\% a pokles maloobchodných tržieb o 20,5\% za obdobie prvých dvoch mesiacov v roku 2020. Aj akciový trh USA zaznamenal stratu $\mathrm{v}$ biliónoch dolárov, čo malo negatívny vplyv na bohatstvo v krajine a zapríčinilo to aj nižšie HDP. Vedci už l'udskú spoločnost' dávno varovali pred faktom, že infekčné choroby môžu prinútit' obchodné aktivity čelit' novej realite a výzvam, ktoré môžu vážne ovplyvnit' prevádzku podnikov a aj manažérske prostredie. Pandémia COVID-19 zapríčinila, že spotrebitelia začali menit' svoje nákupné správanie a začali sa zameriavat' čoraz viac na online nákupy. Manažéri tak musia byt' inovatívny pri hl'adaní alternatívnych foriem dodávok tovaru, ktoré zvýšia záujem spotrebitel’ov o nákup a ul'ahčia a zlepšia aj celkovú komunikáciu medzi podnikmi a spotrebitel'mi. [2, 3]

Pandémia COVID-19 zapríčinila v roku 2020 prudký nárast online obchodu. Zavedené lockdowny a iné prísne opatrenia v jednotlivých krajinách sveta zapríčinili, že sa zvýšilo

\footnotetext{
${ }^{1}$ Ing. Peter Jucha., Žilinská univerzita, Univerzitná 8215/1, 01026 Žilina, Slovensko, e-mail: peter.jucha@fpedas.uniza.sk

${ }^{2}$ Dr.h.c prof. Ing. Tatiana Čorejová, PhD., Žilinská univerzita, Univerzitná 8215/1, 01026 Žilina, Slovensko, e-mail: tatiana.corejova@uniza.sk
} 
využitie digitálnych médií a zariadení v oblasti ekonomiky ale aj celkovo v celej spoločnosti. Vzniknutá kríza môže vyvíjat' tlak na inovácie a na ich šírenie z dôvodu meniacich sa sociálno-politických kontextov. [4]

\section{Ciel' a metodológia}

Hlavným ciel’om príspevku bolo analyzovat' sekundárne zdroje a na základe získaných informácií zhrnút', ako pandémia COVID-19 ovplyvnila elektronický obchod v roku 2020. Na dosiahnutie tohto ciel'a sme vychádzali z analýzy sekundárnych zdrojov, ktoré sa konkrétnou témou zaoberali.

Východiskovými zdrojmi boli články z renomovanej databázy Web of Science. Pre potreby spracovania výsledkov príspevku, boli analyzované internetové zdroje, ktoré obsahovali štatistiky a informácie o stave elektronického obchodu v roku 2020.

\section{Výsledky}

V roku 2020 dosiahol objem online predaja celosvetovo $27,6 \%$ rast a hodnotu 4,28 biliónov dolárov. 18\% všetkých maloobchodných predajov sa v roku 2020 uskutočnil prostredníctvom elektronického obchodu. A aj ked’ elektronický obchod dokázal v roku 2020 prekonat' očakávania, tak celkový celosvetový maloobchodný predaj klesol o 3\%. Na Obrázku 1 je možné vidiet' hodnotu online predaja aj za predchádzajúce roky. Čísla sú uvedené v miliardách dolárov. [5, 6]

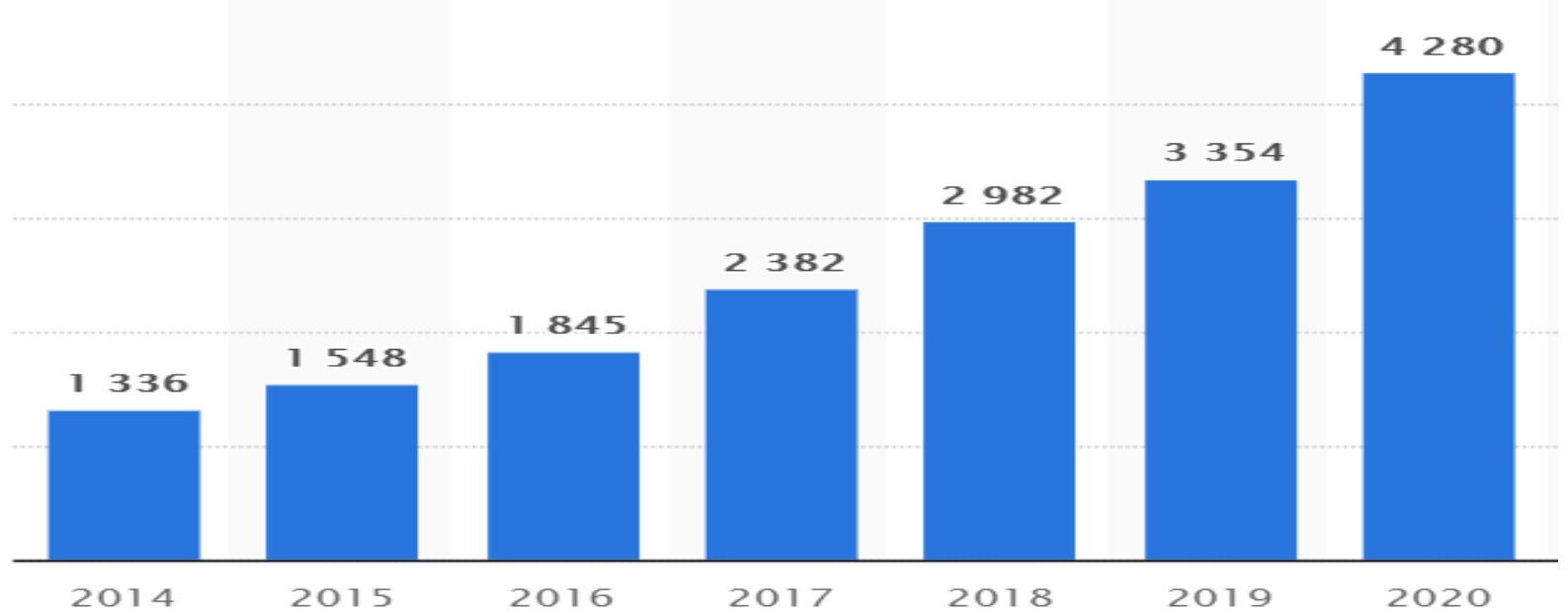

Obrázok 1: Celosvetový maloobchodný predaj elektronického obchodu od roku 2014 do roku 2020 Zdroj: [6]

V októbri 2020, Litovská technologická spoločnost', uskutočnila prieskum medzi 100 osobami, ktoré mali rozhodovacie právomoci v oblasti elektronického obchodu v Európe a Severnej Amerike. Väčšina prevádzkovatel'ov elektronického obchodu zaznamenala, počas locdownu na jar 2020, nárast tržieb. Na základe uskutočneného prieskumu, $90 \%$ podnikov zaznamenalo nárast online predaja, pričom $50 \%$ respondentov taktiež tvrdilo, že ich predaj vzrástol o viac ako $100 \%$. Aj napriek takýmto pozitívnym číslam, $6 \%$ respondentov uviedlo, že ich tržby z online predaja počas jarného lockdownu klesli. $86 \%$ respondentov d'alej tvrdilo, že aj po skončení lockdownu, ked' už začali spotrebitelia opät' nakupovat' aj v kamenných predajniach, ich online príjmy rástli a iba $4 \%$ respondentov uviedlo, že ich online príjmy následne klesli. [7] 


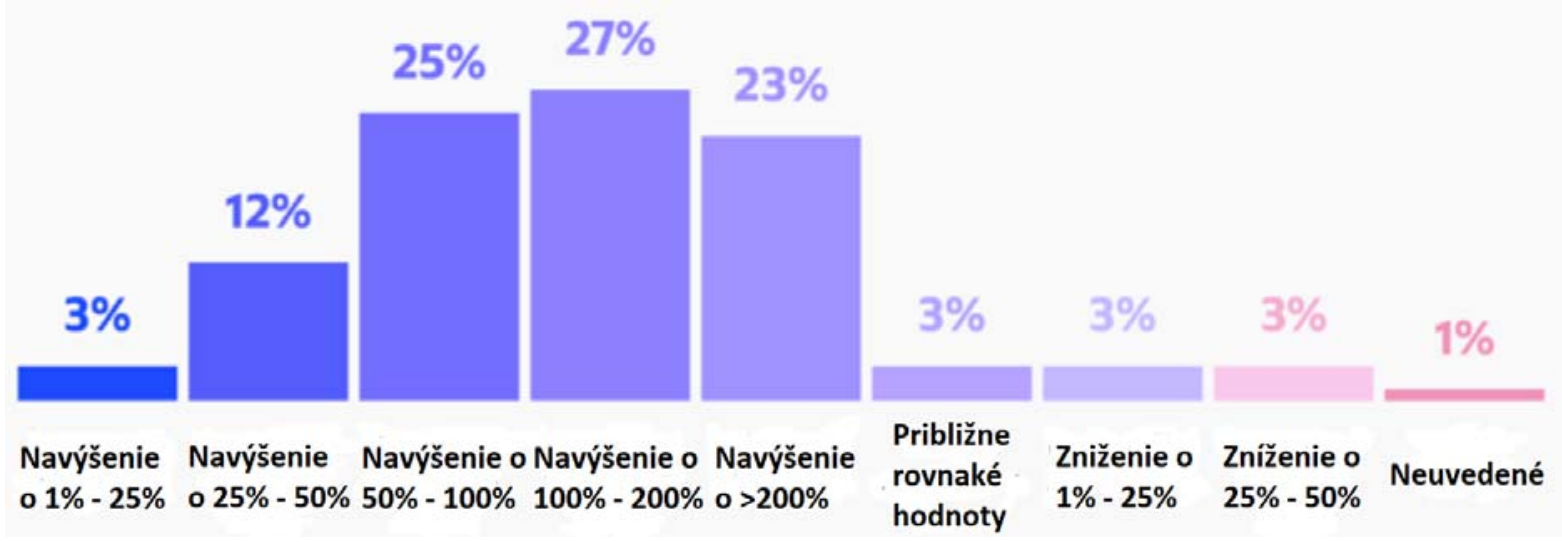

Obrázok 2: Zmeny online príjmu počas jarného lockdownu 2020 v porovnaní s obdobím pred ním Zdroj: [7]

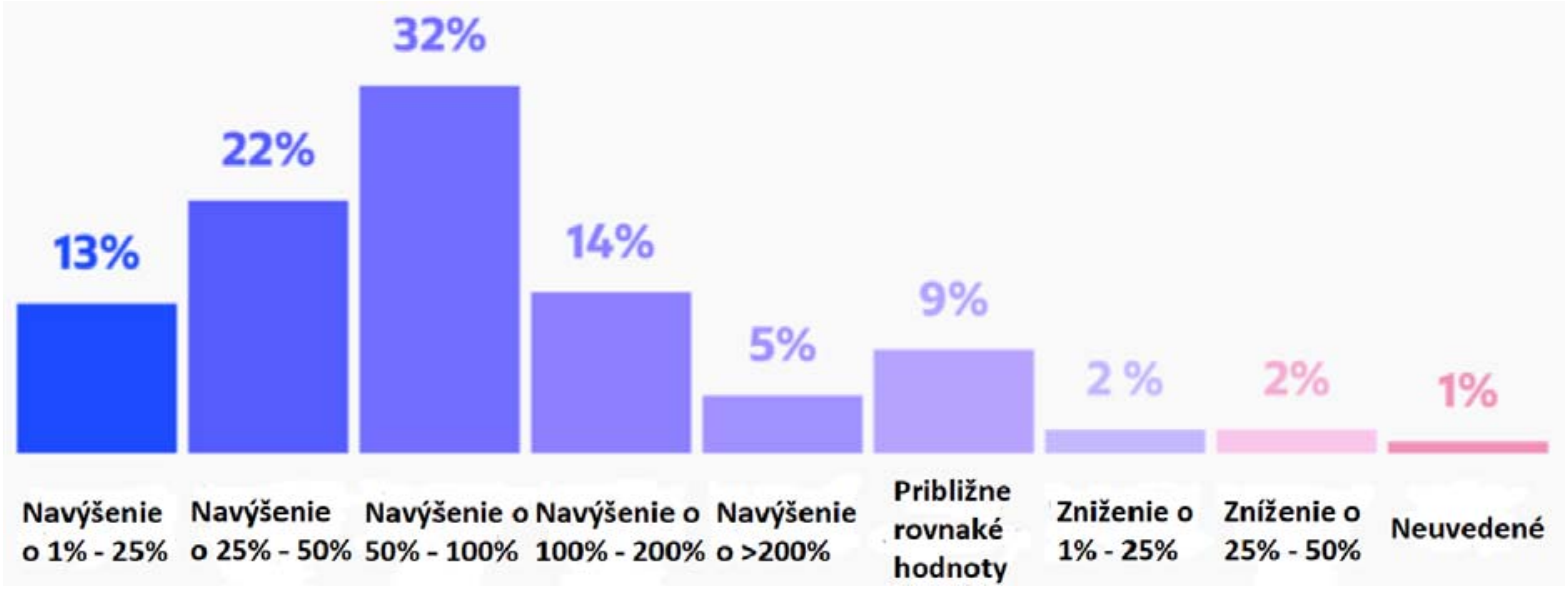

Obrázok 3: Zmeny online príjmu v období po jarnom lockdowne 2020 v porovnaní s obdobím pred ním Zdroj: [7]

$\mathrm{Na}$ základe rôznych štatistík je vidiet', že podiel elektronického obchodu na maloobchodnom predaji, sa stabilne zvyšuje už od roku 2013. Online predaj vtedy tvoril 7,6\% $\mathrm{z}$ celkového maloobchodného predaja. V roku 2019 to už bolo $16 \%$. Pandémia ale tento nárast urýchlila. [7]

Napríklad, ešte v roku 2018, celosvetový predaj v rámci elektronického obchodu nedosahoval hranicu ani troch biliónov dolárov. A v priebehu roka 2020 sa dostal cez hranicu štyroch biliónov dolárov. Odhaduje sa, že do roku 2022 bude objem online predaja na úrovni 5 biliónov dolárov a do roku 2024 na úrovni 6 biliónov dolárov. [5] 


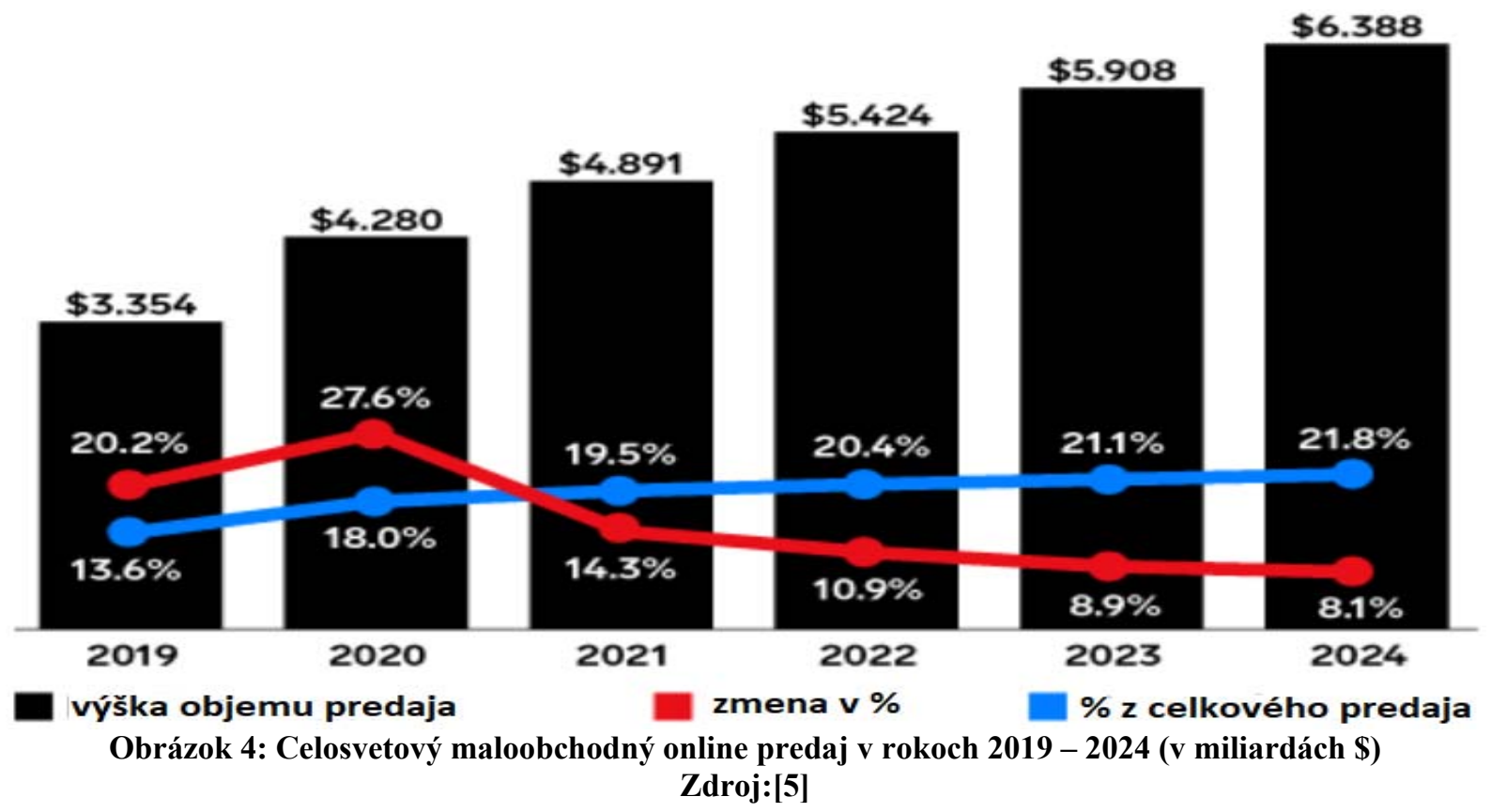

V Amerike objem predaja elektronického obchodu dosiahol, už v druhom štvrt'roku 2020, hodnotu 211,5 miliárd dolárov a medziročný nárast tak predstavoval 44,5\%. Oproti prvému štvrt'roku 2020, kedy mal objem predaja hodnotu 160,3 miliárd dolárov, išlo o $32 \%$ nárast objemu predaja. V tret'om štvrt'roku 2020 tržby mierne poklesli pričom ich hodnota bola približne na úrovni 210 miliárd dolárov. Oproti tretiemu štvrt'roku 2019 to ale stále predstavuje nárast a to konkrétne o 37\%. V poslednom štvrt'roku 2020 sa objem predaja elektronického obchodu dostal na hodnotu 206,6 miliárd dolárov s nárastom o 14\% oproti štvrtému štvrt'roku 2019. Celkovo sa tak objem online predaja medziročne zvýšil o $31,8 \%$ z 598 miliárd dolárov v roku 2019 na 790 miliárd dolárov v roku 2020. [8, 9, 10, 11, 12]

V západnej Európe sa maloobchodný predaj elektronického obchodu, v dôsledku pandémie, v roku 2020 zvýšil o 26,3\% na 481,54 miliárd EUR čo je 539,18 miliárd dolárov. Stredná a Východná Európa zaznamenali nárast o 29,1\%. [13, 14]

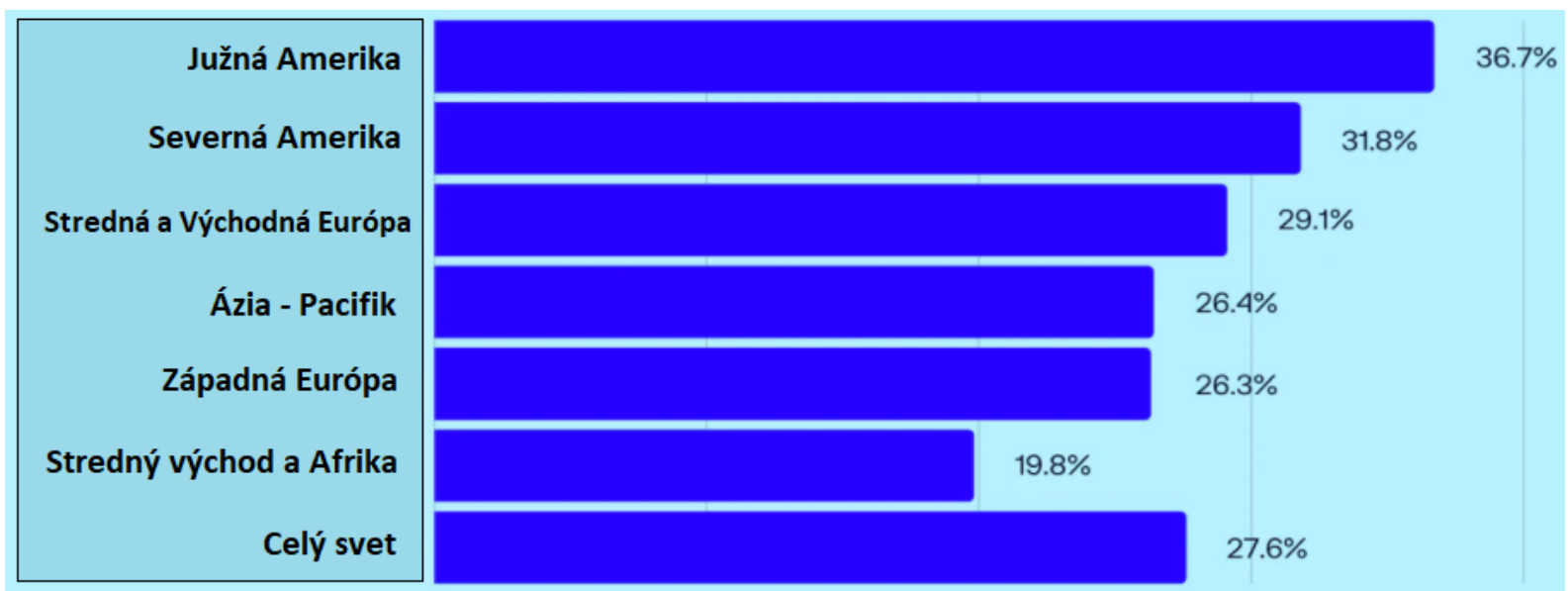

Obrázok 5: Rast predaja elektronického obchodu podl’a regiónov (2020) Zdroj: [14]

Obyvatelia Slovenska minuli, za rok 2020, 1,75 miliardy EUR za online nákupy. Tie tak oproti roku 2019 predstavujú 29\% nárast. Rast elektronického obchodu na Slovensku do značnej miery kopíroval obdobia, kedy boli v krajine zavedené najprísnejšie bezpečnostné obmedzenia. Konkrétne išlo o obdobia v marci a apríli a následne počas jesene 
a predvianočných nákupov. Najväčší podiel na obrate mala elektronika, ktorá tvorila viac ako jednu tretinu všetkých nákupov. Nasledovali ju produkty určené pre dom a záhradu, ktorých podiel predstavoval jednu pätinu na obrate. Dalšími v poradí boli oblečenie, móda a športové vybavenie. Až o 93\% sa zvýšil záujem o jedlo a nápoje a takmer o polovicu vzrástli aj erotické pomôcky. [15]

Návštevnost' webových stránok online predajcov taktiež zaznamenala v roku 2020 nárast. Semrush a OWOX výskum, zameraný na návštevnost' webových stránok online predajcov, porovnával obdobie od 1. marca do 31. októbra za rok 2019 aj za rok 2020. Vzorka založená na údajoch služby Semrush pozostávala z 272 miliárd návštev webových stránok online predajcov a 7064 webových stránok online predajcov v USA a Európe. V závislosti od priemerného počtu návštev webových stránok za mesiac, boli jednotlivé webové stránky rozdelené do šiestich skupín podl'a návštevnosti. Webové stránky, ktorých návštevnost' neprekročila hodnotu tisíc návštev, neboli súčast'ou tohto výskumu. [16]

Výskum ukázal, že celkový počet návštev sa, v období od 1. marca do 31. októbra v roku 2020, zvýšil, oproti roku 2019, o 27\%. Tabul'ka nižšie obsahuje konkrétne údaje. [16]

Tabul'ka 1: Rozdiel návštevnosti webových stránok medzi rokmi 2019 a 2020

\begin{tabular}{|c|c|c|c|c|}
\hline $\begin{array}{c}\text { Skupina webovej } \\
\text { stránky podl'a } \\
\text { návštevnosti }\end{array}$ & $\begin{array}{c}\text { Počet } \\
\text { webstránok }\end{array}$ & $\begin{array}{c}\text { Celková } \\
\text { návštevnost' za } \\
\text { rok 2019 }\end{array}$ & $\begin{array}{c}\text { Celková } \\
\text { návštevnost' za } \\
\text { rok 2020 }\end{array}$ & Rozdiel \\
\hline 1 tis. -10 tis. & 1377 & 54,3 mil. & 40,9 mil. & $-25 \%$ \\
\hline 10 tis. -100 tis. & 1732 & 605,7 mil. & 738,3 mil. & $22 \%$ \\
\hline 100 tis. -1 mil. & 1505 & 4,9 bil. & 6,4 bil. & $29 \%$ \\
\hline 1 mil. -10 mil. & 769 & 20,7 bil. & 26,4 bil. & $28 \%$ \\
\hline 10 mil. + & 163 & 93,6 bil. & 118,6 bil. & $27 \%$ \\
\hline Celkovo & $\mathbf{5 5 4 6}$ & $\mathbf{1 1 9 , 9}$ bil. & $\mathbf{1 5 2 , 2}$ bil. & $\mathbf{2 7 \%}$ \\
\hline
\end{tabular}

Zdroj: [16]

\section{Záver}

Na základe analyzovaných zdrojov a sekundárnych výskumov je vidiet' ako pandémia v roku 2020 ovplyvnila oblast' elektronického obchodu. Objem online predaja sa už dlhšiu dobu každoročne zvyšuje, ale v roku 2020 bol tento nárast výraznejší. Medziročný nárast objemu online predaja sa, od roku 2014 do roku 2019, celosvetovo pohyboval v rozmedzí od 200 miliárd po 600 miliárd dolárov. V roku 2020 medziročný nárast objemu online predaja dosiahol hodnotu až 926 miliárd dolárov, čo v porovnaní s predošlým rokom predstavuje približne 2,5-násobok a napríklad v porovnaní s rokom 2015 je to až takmer 4,5-násobok.

To, že pandémia mala a stále má pozitívny vplyv na elektronický obchod dokazuje aj fakt, že až $90 \%$ online predajcov sa zvýšili ich predaje, pričom $50 \%$ tvrdilo, že išlo až o 100\% navýšenie.

Pandémia má výrazný vplyv aj na nákupné správanie zákazníkov. Na základe údajov zo Slovenska je možné vidiet', že sa zvýšil predovšetkým online predaj potravín, produktov pre dom a záhradu, oblečenia a športových pomôcok. Dá sa predpokladat', že hlavným dôvodom objednávania potravín, bola možnost' vyhnút' sa kontaktu s l'ud'mi a znížit' tak riziko nákazy vírusom. Čo sa týka ostatných menovaných produktov, tak hlavným dôvodom bol pravdepodobne zákaz vychádzania a ostatné bezpečnostné opatrenia, ktoré mnoho l'udí zavreli na celé mesiace doma. Preto sa mnohí začali venovat' cvičeniu alebo pracovali na dome.

Predpokladá sa ale, že d'alší rok objem online predaja, v porovnaní s rokom 2020, poklesne. Taktiež je ale možné predpokladat', že nákupné správanie zákazníkov sa dlhodobo zmení a napríklad potraviny si budú aj v d'alších rokoch objednávat' častejšie ako doteraz. 


\section{Literatúra}

[1] NEGRUTIU, C.: Major Trends and New Business Models in Supply Chain and Entrepreneurship After the COVID-19 Crisis. Studia Universitatis Vasile Goldis Arad, Seria Stiinte Economice, 2021, s. 84-96, ISSN 1584-2339

[2] AL-MAAITAH, TA., MAJAH, T., ALSOUD, M., AL-MAAITAH, DA.: The Impact of COVID-19 on the Electronic Commerce Users Behavior. Journal of Contemporary Issues in Business and Government, 2021, s. 784-793, ISSN 2204-1990

[3] TRAN, LTT.: Managing the effectiveness of e-commerce platforms in a pandemic. Journal of Retaling and Consumer Services, 2021, s. 1-9, ISSN 0969-6989

[4] DANNENBERG, P., FUCHS, M., RIEDLER, T., WIEDEMANN, C.: Digital Transition by COVID-19 Pandemic? The German Food Online Retail. Tijdschrift voor Economische en Sociale Geografie, 2020, s. 543-560, ISSN 0040-747X

[5] GRUENWEDEL, E.: Report: Global E-commerce Reached $\$ 4$ Trillion in 2020. [online]. Dostupné na: https://www.mediaplaynews.com/report-global-e-commerce-reached-4trillion-in-2020/

[6] SABANOGLU, T.: Global retail e-commerce sales 2014-2024. 2021. [online]. Dostupné na: https://www.statista.com/statistics/379046/worldwide-retail-e-commerce-sales/

[7] The impact of Covid-19 on ecommerce. 2021. [online]. Dostupné na: https://ecommercenews.eu/the-impact-of-covid-19-on-ecommerce/

[8] E-Commerce's Impact on Small Business in the Age of COVID-19. 2021. [online]. Dostupné na: https://www.natlawreview.com/article/e-commerce-s-impact-smallbusiness-age-covid-19

[9] PALMER, A.: Coronavirus pandemic turbocharges online sales, which were up more than $31 \%$ in just three months. 2020. [online]. Dostupné na: https://www.cnbc.com/2020/08/18/e-commerce-sales-grew-more-than-30percentbetween-q1-and-q2.html

[10]COPPOLA, D.: Quarterly U.S. e-commerce retail sales 2009-2020. 2021. [online]. Dostupné na: https://www.statista.com/statistics/187443/quarterly-e-commerce-sales-inthe-the-us/

[11] Dostupné na: https://www.freightwaves.com/news/global-e-commerce-sales-jump-24-indecember

[12] LEBARON, J.: Ecommerce Trends for 2021. 2021. [online]. Dostupné na: https://pattern.com/blog/ecommerce-trends-for-2021/

[13] ABRAMS, K.: Western Europe Retail Trends 2021. 2021. [online]. Dostupné na: https://www.emarketer.com/content/western-europe-retail-trends-2021

[14] Global ecommerce sales growth (2019-2024). [online]. Dostupné na: https://www.oberlo.com/statistics/global-ecommerce-sales-growth

[15] Pandémia vyhnala e-commerce k takmer tretinovému rastu. 2021. [online]. Dostupné na: https://touchit.sk/pandemia-vyhnala-e-commerce-k-takmer-tretinovemu-rastu/330208

[16] KASHUBA, M.: The impact of COVID-19 on e-commerce. 2021. [online]. Dostupné na: https://customerthink.com/the-impact-of-covid-19-on-e-commerce/

\section{Grantová podpora}

Táto publikácia vznikla vd’aka podpore projektu VEGA 1/0011/21 Výskum interakcií medzi novými emergentnými technológiami, výkonnostou podnikov a odvetví založených na siet'ovej technologickej infraštruktúre, uplatňovaním nových business modelov a inštitucionálnym regulačným, environmentálnym a sociálnym prostredím . 